\title{
INTERESTS OF THE EUROPEAN COUNCIL AND THE EUROPEAN UNION IN THE AREA OF ENVIRONMENT PROTECTION
}

\author{
E. Paraschiv
}

\section{Elena Paraschiv}

Faculty of Law and Public Administration, Râmnicu Vâlcea, "Spiru Haret" University, Râmnicu Vâlcea, Romania

*Correspondence: Elena Paraschiv, 30 General Magheru St., Râmnicu Vâlcea, Vâlcea, Romania

E-mail: e.paraschiv.dvl@ spiruharet.ro

\section{Abstract}

Due to the environment's importance in the development of life, protecting it has also become the main concern of regional organizations worldwide, an outstanding contribution in this sense having been brought by the European Council and the institutions of the European Union, which, by adopting numerous legal instruments, significantly contributed to the preservation of nature and protection of the environment, also establishing several interdictions, behevioural norms and principles that are specific to the domain researched, as well as sactions applicable to those who affect these values by committing illicit acts.

Key-words: preservation and protection of the environment, legal instruments, environmental law

\section{Introduction}

In the framework of its preoccupations regarding environment protection, the European Council adopted a convention ${ }^{l}$ which aims at uniforming and stimulating legal regulations of the member states regarding the damage compensation resulted from a perilous activity and environment restoration. These are qualified as "dangerous" activities resulting from the use of harmful substances, but also any production or usage of genetically modified organisms, any use of an microorganism susceptible to present risks for humans or the environment, as well as any exploitation which deals with or deposits waste ${ }^{2}$.The liability The operator or the person who exercits control is generally liable for the acts.

The contribution of the European Court of Human Rights' practice to environment protection

Even though in the European Convention of human rights and fundamental liberties, environment protection is not listed among the treated subjects ${ }^{3}$, this issue is revealed by the

\footnotetext{
${ }^{1}$ Convention on civil responsibility for damage resulting from dangerous activities to the environment, adopted at Lugano, in the date of 21 June 1993.

${ }_{2}$ Managing waste by the member states of the European Union was recently regulated, by the Directive 2008/98/CE of the European Parliament and the Council, from the 19th of November 2008, regarding waste and repealing certain Directives.

${ }^{3}$ Unlike the European Convention, other regional instruments explicitly consecrate this right. Thus, in art. 24 of the African Charter on Human and Peoples of 27 June 1981, it is stipulated that "All peoples have the right to a satisfactory, global and suitable environment for their development", and the Protocol of San Salvador, in addition to the American Convention on Human Rights, on economic, social and Cultural Rights of 17 November 1988, is the first convention which included the right to a wholesome environment in the corpus of human rights, saying that "Everyone has the right to live in a salubrious environment and to benefit of essential, collective equipment" (art. $11 \S 1)$.
} 
practice of the European Court of Human Rights ${ }^{4}$, the evolution of realities imposing the consecration of certain norms in a jurisprudential manner.

Thus, in the decision from 18 December 1996, pronounced by the European Court of Human Rights in the case Loizidou vs Turkey ${ }^{5}$ it is illustrated, concerning the European Convention, as a treaty of guaranteeing human rights, that this is a "live instrument which should be interpreted in the light of the present life's conditions. Moreover, its objective and aim demand an interpretation and application of its dispositions in a way which would make the demands practical and effective".

Practically, in this situation, the praetorian technique of "indirect protection" was used, which permits the extension of protection of certain rights guaranteed by the Convention, concerning rights which are not explicitly stipulated in it. Consequently, in the cases of environment damage, the infringement of a "right to a healthy environment" cannot be brought directly to the European Court of Human Rights, as this right allocated to the individual does not benefit from a guarantee except by "attraction" from another right and under its cover.

Although it was initially suggested - for the protection of the right to a healthy environment- to invoke the right to health and welfare which results from the right to life, stipulated in art. 2 in the Convention, the Court preferred to appeal to art. $8 \S 1$, which recognizes the right of any individual to the respect of its own private, familial life and domicile, as well as to art. 6.1. that guarantees the right to a fair trial..

The European judge does not reduce the significance of the term "private life" to the intimate sphere of personal relationships, but extends it to the right of the individual "to establish and develop relations with his peers, consequently covering the professional or commercial activities, as well as the places it is exercised"6.

In one of its sentences ${ }^{7}$, the European Court of Human Rights admitted that the noise from the planes :reduced the quality of the private life and tranquillity at home ${ }^{8}$ and decide that serious harm brought to the environment may affect the welfare of a person and may prevent her from normally using the benefit of its domicile, which leads to harming her private and family life, even if it does not represent a grave danger for the health of the person ${ }^{9}$.

The Court also extended the sphere of application of art. 8 in the Convention to the protection of health affected by the exposure of British soldiers to nuclear radiations ${ }^{10}$, considering that it "embodies a sufficiently strong connection with their private family life".

\footnotetext{
${ }^{4}$ According to the European Court of Human Rights on the Guerra and Others v. Italy, 19 February 1998, environmental protection intervenes in an incidental manner towards the protection of privacy and family life, asserting itself as an inseparable element of the "right to a healthy environment ". In the decision it is stated that the emissions of a hazardous chemical plant has a" direct impact "on the right protected by art. 8 of the Convention.

Available on the website of the European Court of Human Rights (http://www.echr.coe.int/ECHR/EN/Header/Case-Law/Hudoc/Hudoc+database/, accessed on 09.20.2011), as and further commented.

${ }^{6}$ The Niemietz v. Germany case, decision of 16 December 1992, § 29 A251B.

${ }^{7}$ Sentence from 21.02.1990, $§ 40$, in the case Powel and Rayner.

${ }^{8}$ The López-Ostra v. Spain case, the general sentence of 9 December 1994 according to which the European court stated that the right of every individual "to respect of his private and family life and home" implies the right to live in a healthy environment.

9 The notion of private life means that it involves a certain level of comfort, "of wealth" without which the respect of the right of private or family life or home would not be effective, but only fictional.

${ }^{10}$ The decision from 9 June 1988, in the case Mc Ginley and Egan Vs Great Britain, in which it was stated that when dangerous activities are being developed, such as nuclear experiments which may result in "devastating and hidden consequences" upon the health of a person, those interested must have access to pertinent information regarding these documents. Moreover, in the case of Guerra and Others v. Italy it was considered that art. 10 of the European Convention demands states to provide environmental information necessary for the protection of individuals against whom negative effects may be produced.
} 
The practice of the European Court of Human Rights also stated the obligation of the state parties to the Convention by adopting "positive measures" destined to guarantee the right to a healthy environment, sanctioning the passivity of public authorities ${ }^{11}$.

In another case $\mathrm{e}^{12}$, the European Court of Human Rights motivated the admittance of the request and invoked the dispositions of the Constitutions of the respondent State, which guarantees the right to live in a healthy environment.

The Court also established that a state may also respond when, as a result of certain military actions- legal or not- it breaches the environment norms in the areas situated outside the national territory, if in practice it exercises control upon the respective areas.

As a conclusion, in interpreting art. $8 \S 1$ and art. $6 \S 1$ (the right to a fair trial) from the European Convention of Human Rights, the European Court of Human Rights considers the right to a healthy environment as being an individual right from the category of intangible civil rights, which may be the object of certain derogations only in exceptional cases ${ }^{13}$, and the states may limit it only by means of the law ${ }^{14}$.

\section{The Contribution of the European Union Court of Justice in the area of environment protection}

The protection mechanism of rights concerning a healthy environment were achieved by mean of the jurisprudence belonging to the European Union Court of Justice, as well as through the existence of principles which are common to the state members referring to this issue. In the framework of the European Union there continue to exist concerns for the creation of a complete and unitary regime concerning environment protection in the area of the European Union, the regulations issued ${ }^{15}$ being based on the principle, as shown, that the polluter pays ${ }^{16}$.

The Court of Justice of the European Union is developing an intense activity on establishing the guilt of member states for not complying with the obligations laid down in the norms of the European Union and with harmful effects upon the environment. In this sense we exemplify by mentioning the decision pronounced on the 4th of October 2007 by the Court of Justice of the European Union, Sixth Chamber, in the case C-523/06 regarding the action of establishing non-compliance of a state member of the obligations regarding the reception of waste resulting from ship exploitation and cargo residues, with negative consequences upon the environment (Directive 2000/59/EC, article 226 from the Treaty establishing the European Community) ${ }^{17}$.

\footnotetext{
${ }^{11}$ The sentence stated by the European Court of Human Rights in 1994, in the López-Ostra v. Spain case, which also establishes the fact that the measures taken by the states to ensure a healthy environment must be practical and effective, ensuring the effectiveness of protected rights, even against negative actions of third parties.

${ }^{12}$ Decision from 10 December 2004, in the case Taskin and others against Turkey.

${ }^{13}$ Art. 15 from the European Convention of human rights.

${ }^{14}$ Article $8 \S 2$ in the Convention provides that the limitation of such rights is a measure which; in a democratic society is necessary to national security, public or economic safety of the country, or protection of the rights and liberties of citizens in general.

15 On the 9th of February 2000, The European Commission adopted the "White Charter on environmental liability," and on the 23rd of January 2002 the proposal of the European Parliament and of the Council concerning environmental responsibility to prevent and repair environmental damage was published (COM 2002/17 final), which was amended on 26 January 2004 (COM 2004/55 final) and 21 April 2004 (Directive 2004/35/EC).

${ }^{16}$ The "polluter pays" was introduced in the EU regulations by the Single European Act of 1987 (art.130R.2 and art.130S.5), regulation also maintained in the Treaty of Amsterdam in 1997; an application of this principle is found in the Council Regulation no. 1013/2006 regarding the supervision and control of waste shipments within and outside the European Community. " The Polluter pays" principle is the foundation of Civil Liability Directive 2004/35/EC regarding the prevention and remedying of environmental damage. "An example in this respect, is the Court of Justice of the European Union (Grand Chamber) of 9 March 2010 in Joined Cases C 379/08 and C 380/08.

17 The applicant, namely the European Commission, filed on 22 January 2006, infringement proceedings under Art. 226 of the Treaty establishing the European Community, against the defendant, namely the Republic of Finland. The Court of Justice of the European Union, by the decision pronounced on the 4th of October 2007,
} 
By studying the practice of the Court of Justice of the European Union, we may state that there are also other decisions in which non-compliance of the member states regarding waste management resulted from electric and electronic equipment ${ }^{18}$ was established, along with the lack of necessary measures to shut down or rehabilitate illegal or uncontrolled waste deposits $^{19}$, non-compliance with the obligation to elaborate management plans of dangerous waste $^{20}$ etc. Likewise, decisions were adopted in the domain of water quality protection, such as the decision of the European Union Court of Justice, pronounced on the date of the 25th of October 2007, in the case C-248/05, referring to non-compliance with the obligations of a state, of protection of groundwater against pollution caused by hazardous substances (Directive 80/68/CEE, article 226 of the Treaty establishing the European Community) ${ }^{21}$.

By researching the practice of the European Union Court of Justice, we state that multiple decisions were pronounced by which the non-compliance of the directives issued by the European institutions regarding the protection of the quality of the water were observed, such as: not taking adequate treatment of urban waste water from more urban areas ${ }^{22}$, noncompliance with obligations concerning the guarantee of the quality of water destined for

stated that, due to the fact that the Republic failed to establish and apply the reception and handling plans of waste in all the ports, the Republic of Finland did not comply with all the liabilities based on art.5 par.1 and art.16 par.1 in the Directive 2000/59/EC of the European Parliament and the Council, from the 27th of November 2000, regarding port reception facilities for ship-generated waste and cargo residues.

18 The plaintiff, the European Commission, formulated on the 10th of March 2006 proceedings against the United Kingdom of Great Britain and Northern Ireland, based on the art. 226 from the Treaty establishing the European Community. The Court of Justice of the European Union, by the decision pronounced on the 1st of 2007 stated that because of not adopting acts with law power and the necessary acts to conform with the Directive 2002/96/EC of the European Parliament and of the Council, from the 27th of January 2003, regarding waste and electric and electronic equipment and the Directive 2003/108/EC of the European Parliament and of the Council, from the 8th of December 2003, of amendment of the Directive 2002/96/EC, the respondent states did not fulfill their responsibilities stipulated in these directives, case C-139/06 (JO C108 from 6 November 2006, p. 14).

${ }^{19}$ The plaintiff, namely the European Commission formulated an action to court on 29 November 2005, against France under art. 226 of the Treaty establishing the European Community. By the decision pronounced on the 29th of March 2007 in the case C-423/05 (Official Gazette C48 from the 25th of February 2006, p. 14), the European Union Court of Justice noticed that, not taking all the possible measures to ensure observance of art. 4.8 and 9 from the 75/442/EEC Directive of the Council, from the 15th of July 1975, regarding waste, as amended by the Directive 91/156/EEC of the Council, from the 18th of March 1991, and of art. 14 let. a, b and c from the Directive 1999/31/EC of the Council, from the 26th of April 1999, regarding the waste deposits, the plaintiff has not fulfilled the obligations undertaken in conformity with the dispositions.

${ }^{20}$ The European Commission brought to court, on the 8th of February 2008, the case against the Italian Republic, in conformity with art. 226 of the Treaty establishing the European Community. By the decision pronounced on the 14th of February 2007, in the case C-82/06 (Official Gazette C86 from the 6th of April 2006, p. 17), the European Union Court of Justice noticed that the plaintiff has not fulfilled the obligations undertaken in conformity with art. 7 par. 1 in the Directive 75/442/CEE of the Council from the 15th of July 1975, regarding waste as amended by the Decision 91/156/EEC of the Council, from the 18th of March 1991, as it did not develop a waste management plan for the regions Rimini, Lazio Friuli - Venezia Giulia and Apulia, as well as for the autonomous region Bolzano- Alto Adige and province Rimini.

${ }^{21}$ On the 14th of June 2005, the plaintiff namely the European Commission formulated an action to court against the plaintiff Ireland, which stated the unfulfillment of obligations, in conformity with art. 226 from the Treaty establishing the European Community. By the decision pronounced on the 25th of October 2007, the European Union Court of Justice noticed that, due to the fact that it did not take all necessary measure to conform to articles 4, 5, 7 and 10 from the 80/68/EEC Directive of the Council, from the 17th of December 1979, regarding the protection of underground water against pollution caused by certain dangerous substances concerning the municipal waste deposits of Ballymurtagh (Wicklow shire), Ireland has not fulfilled the obligations undertaken in conformity with this directive (Official gazette C205 from the 20th of August 2005, p. 9).

${ }^{22}$ The European Commission has formulated action on the 18th of November 2005, against Great Britain and Northern Ireland, in conformity with art. 226 from Treaty establishing the European Community. The European Union Court of Justice stated, by the decision pronounced on the 25th of January 2007, in the case C-405/05 (Official Gazette C48 from the 26th February 2006, p. 11) that the plaintiffs did not take the necessary measures because, until 31 December 2000, they would fulfill their obligations to adequately treat wastewater from multiple urban centres in the two countries, thus breaching art. 4 par. 1 and 3 from the 91/271/EEC Directive of the Council, from the 21st of May 1991, regarding treatment of urban wastewater. 
consumption, which had a higher concentration of nitrates and pesticides ${ }^{23}$, urban waste water discharge into a sensitive area without adequate treatment ${ }^{24}$.

The Court of Justice of the European Union revealed, by numerous decisions pronounced and by infringements of the European Union directives referring to environment protection, other domains, such asa integrated pollution prevention and control, access to information, public participation in decision making and access to justice regarding environmental problems, the air quality and climatic changes, preserving natural habitats and species of savage flora and fauna, the evaluation of the effects of certain plans, programs, public and private projects upon the environment etc.

From the decisions mentioned the one pronounced on the 3rd of May 2007, in the case C-391/06, upon establishing the European Commission from the 26th of September 2006 was submitted to analysis, based on art. 226 from the Treaty establishing the European Community, against Ireland. The European Union Court of Justice stated that, by not adopting in the term established of the necessary legal documents and administrative documents necessary to conform to the 2003/4/EC Directive of the European Parliament and the Council, from the 28 of January, 2003 regarding public access to environment information and abrogation of the 90/313/CEE Directive of the Council, Ireland has not fulfilled the obligations which it undertook based on this directive. Moreover, by analysing the decision pronounced on the 11th of January 2007 by the Court of Justice of the European Union in the case C-183/05, upon establishing the European Committee, in conformity with art. 226 from the Treaty establishing the European Community against Ireland, we consider the conclusion of the court that, by not adopting all necessary specific measures for effectively applying the rigorous protection system, stipulated in art. 12 par. 1 from the Directive 92/43/CEE of the Council, from the 21th of May 1992, regarding natural habitats preservation along with the species of savage flora and fauna, Ireland has not fulfilled the obligations undertaken in conformity with this directive. Moreover, by analysing the decision pronounced by the European Union Court of Justice from the 24th of May, in case C-376/06, upon establishing the European Commission from the 14th of September 2006 against Portugal, we consider the conclusion of the court, that by not adopting in the term established of the necessary legal documents and administrative documents necessary to conform to the 2001/42/EC Directive of the European Parliament and the Council, from the 27th of June 2001, regarding the evaluation of effects of certain plans and programs upon the environment, Portugal has nt fulfilled the obligations undertaken in conformity with this directive.

According to international requests, which advise states to adopt measures and sanctions to ensure environment protection ${ }^{25}$, with the regulations of the European Union, as

\footnotetext{
${ }^{23}$ The European Commission has formulated action on the 13th of March 2007, against France, stating the unfulfillment of obligations, in conformity with art. 226 from the Treaty establishing the European Community. By the decision pronounced on the 31st of January 2008, in the case C-147/07 (Official Gazette C95 from the 28th of April 2007, p. 6) The European Union Court of Justice stated that, by not adopting all necessary measures to conform with art. 4 in the 95/83/EC Directive of the Council from the 3th of November 1998, regarding the quality of water destined for human consumption, the plaintiff did not fulfill the obligations undertaken in conformity with this directive.

${ }^{24}$ The European Commission formulated, on the 18th of May 2005, an action in stating the unfulfillment of obligations, in conformity with art 226 in the Treaty of establishing the European Community against the Kingdom of Spain. By the decision pronounced on the 19th of April 2007, in the case C-219/05 (Official Gazette C96 from 28 April 2007, p. 8), the Court of Justice of the European Union, the fifth Chamber, noticed that the plaintiff did not adopt the necessary measures to guarantee that, commencing with the 31st of December 1998, the underground waters coming from the Succa city, from other regions, were to be submitted to an adequate treatment before their flow in an area considered to be sensitive, thus breaching the dispositions of art. 3 par. 1 and art. 5 par. 2 corroborated with art. 4 par. 4 from the 91/271/ECC Directive of the Council, from the 21st of May 1991, regarding treatment of wastewater.

${ }^{25}$ The international declaration from de la Rio de Janeiro (1992) presents the necessity that the states establish a national legislation regarding liability for pollution and other damages brought to the environment by means of international offenses; the states will predict methods of action brought to courts, for the actions of restoring the damages and losses.
} 
well the analysed international practice, our country regulates legal liability for not observing the norms of environment right, by the Government Emergency Decision no 68/2007 regarding environment liability, referring to the prevention and restoration upon the environment. ${ }^{26}$.

\section{Conclusions}

The fact that pollution knows no boundaries is an undeniable truth. The polluted air and toxic waste circle around the entire Europe and numerous lakes and water flows are divided among several states. Thus, the European Union constitutes a favourable framework for solving these multiple issues, comparative to the more narrow national one and the glob al framework which lacks the constraint force, the common action of the states of the European Union having the ability to manifest by means of a single voice regarding the key-issues of the area.

Qualitative differences between living and working conditions of citizens of those countries may arise by applying divergent economic policies in the various member states of the Union. Likewise, this may lead to economic disparities that affect the proper functioning of the common market. Defining different national norms would prevent the free circulation of goods between the member states, while imposing unequal tasks to enterprises would create distortions of competition. From here results the economic interest of a common policy, especially in the context of establishing a common market after the year 1992.

\section{Bibliography}

M. Duțu, Dreptul mediului, $3^{\text {rd }}$ Edition, “C.H. Beck” Press, Bucharest, 2010;

Petre Maria-Cristina, Drept comunitar al mediului. Culegere de spețe, "Universul Juridic" Press, Bucharest, 2008;

M. Duțu, Principii şi instituții fundamentale de drept comunitar al mediului, Economic Press, Bucharest, 2005;

M. Duțu, Dreptul internaţional al mediului, Economic Press, Bucharest, 2004

Szönyi Dandachi Amira, La Convention sur la protection de l'environnement par le droit pénal, Revue Juridique de l'Environnement, no. 3, 2003;

Sudre Frederic, La protection du droit à l'environnement par la Coureuropéene des droits de l'homme, in the vol. Les Nations Unies et la protection d'environnement, Pedone Press, Paris, 1999.

\footnotetext{
${ }^{26}$ The Emergency Government Ordinance no. 68/28 June 2007 was published in the Official Gazette no. 446 from the $29^{\text {th }}$ of April 2007, was approved by the Law no. 19 from the $29^{\text {th }}$ of February 2008, and then amended and completed by the Emergency Government Ordinance no. 15/2009.
} 